Marquette University

e-Publications@Marquette

$1-1-2004$

\title{
Do Outside Blockholders Influence Corporate Governance Practices?
}

Sarah Peck

Marquette University, sarah.peck@marquette.edu

Accepted version. Corporate Governance, (2004): 81-101. DOI. (C) 2004 Emerald. Used with permission. 
Do Outside Blockholders Influence Corporate Governance Practices?

Sarah W. Peck

Marquette University

JEL classification: G34; G30; G20

Keywords: shareholder activism; corporate governance; money management firms.

\begin{abstract}
This study investigates whether block acquisitions lead to changes in board and CEO compensation characteristics and finds that block purchasers do not play a significant role in improving the firm's governance practices. However, the majority of professional investors have sold their block within a year, suggesting that they do not own their stock long enough to alter governance policies nor to benefit from such changes. For the smaller number of firms where a new blockholder maintains their investment for more than a year, the use of equity based CEO compensation increases while the use of cash based compensation decreases.
\end{abstract}




\section{INTRODUCTION}

Recent scandals at Enron, Global Crossing, Aldephia, Qwest and World Com have led the pundits to declare a crisis in corporate governance and to call for greater vigilance by regulators and analysts of board practices, CEO compensation, and auditor independence. ${ }^{1}$ Shareholder activists also have called upon major stockholders (blockholders), such as mutual funds and money managers, to play a more active role in determining the practices of corporate governance. They have argued that money managers' lack of concern for board independence and CEO compensation have contributed to the crisis in corporate governance. ${ }^{2}$ Prior research suggests that major investors do influence corporate policy by replacing the $\mathrm{CEO}$ and by restructuring the corporation after their purchase of a block of stock (see Bethel, Liebeskind, and Opler, 1998; and Denis and Serrano, 1996; and Barclay and Holderness, 1991). These actions can be taken quickly and their impact can be reflected almost immediately in the price of the stock. No study to date has investigated whether actions that have longer run impacts, such as changes in the independence and effectiveness of the board or changes in the incentive compensation of the $\mathrm{CEO}$, also occur after a block acquisition by a professional investor. This study does and finds most such blockholders simply do not hold their stock long enough to have either the ability or incentive to make longer run changes in the corporation in which they just acquired stock.

\footnotetext{
${ }^{1}$ See "How to Fix Corporate Governance," Special Report- The Crisis in Corporate Governance, Business Week, New York, New York, May 6, 2002.

${ }^{2}$ See "Investors of the world, unite!" Fortune, New York, New York, June 24, 2002.
}

This article is ( $)$ Emerald Group Publishing and permission has been granted for this version to appear here (http://dx.doi.org/10.1016/S1569-3732(04)09004-8). Emerald does not grant permission for this article to be further copied/distributed or hosted elsewhere without the express permission from Emerald Group Publishing Limited. 
In a sample of 159 block acquisitions for 92 firms for 1989 and 1990,

restructurings and the replacement of the CEO increase significantly after an acquisition of a block of stock by an outside investor, a finding consistent with prior studies. There is only weak evidence, however, that the actions of the blockholders lead to greater use of incentive compensation for the CEO. Furthermore, the results for the changes in CEO compensation are strongest for those firms where a new blockholder maintains their investment in the firm for more than a year. There is no evidence that block acquisitions result in a change in the composition of the board or its effectiveness. Foregoing these longer run actions is consistent with this study's findings that almost half of the new blockholders have sold their stake in less than a year after their initial purchase and over $70 \%$ have done so within two years. These results support complaints in the financial press that large institutional holders, mutual fund, and other managers fail to influence corporate governance policies in most firms.

One reason that these investors may not choose to strengthen the effectiveness of the board and CEO compensation contracts is the time required to effect such changes. Given the size of their investment, blockholders may not be willing to wait to make changes that will lead to an increase in stock price. Most existing compensation contracts are re-negotiated annually and, in some cases with long-term performance plans, even less frequently. Thus a new blockholder may have to wait until the contract is up for re-negotiation to make changes in the incentives for the existing CEO.

Board changes are also "sticky." Routine changes in board composition can be made only when stockholders elect directors at the annual meeting. Management largely controls the nominating process and thus a blockholder can only put forth a competing

This article is ( Emerald Group Publishing and permission has been granted for this version to appear here (http://dx.doi.org/10.1016/S1569-3732(04)09004-8). Emerald does not grant permission for this article to be further copied/distributed or hosted elsewhere without the express permission from Emerald Group Publishing Limited. 
slate of nominees by instigating a proxy fight. Furthermore, blockholders often lose the fight because shareholders with small holdings tend to vote with management. Thus blockholders may not get the board they want even if they are willing to wait until the annual meeting and wage a proxy fight. ${ }^{3}$

In contrast, a large blockholder can effect changes in the CEO and the firm's restructuring plans relatively quickly. They can pressure the board into making these changes by using the voting power inherent in their position as large shareholders to implicitly convey their willingness to align themselves with potential bidders in a takeover or other dissident shareholders. ${ }^{4}$ In fact, many researchers have found that outside block acquisitions occur prior to an eventual takeover suggesting that management and the board will find such a threat credible (see Mikkelson and Ruback, 1985; Holderness and Sheehan, 1986; Barclay and Holderness, 1991; Denis and Serrano, 1996; and Peck, 1996). This tacit threat together with 'quiet pressure' can cause the board and the top managers to focus on changes such as replacing the CEO or restructuring the firm that do not require a shareholder vote (see Shleifer and Vishny, 1986, and Del Guercio and Hawkins, 1998). ${ }^{5}$

\footnotetext{
${ }^{3}$ See Dodd and Warner (1983) and "How Shareholder Votes are Legally Rigged," BusinessWeek, New York, New York, May 20, 2002.

4 Alignment can either take the form of tendering their shares to the bidder or voting with the bidder at a special meeting of shareholders called to vote on the takeover/ merger.

${ }^{5}$ Furthermore, CEO replacement and restructuring may lead to greater increases in shareholder value than changes in corporate governance policies. Thus blockholders may be more likely to target firms that are candidates for CEO replacement than firms that are candidates for corporate governance changes. The difference in the increase in shareholder wealth from these two types of changes (if any) is not addressed in this study, but the timing is. See the discussion of this study's limitations in the last section of the paper.
}

This article is ( E) Emerald Group Publishing and permission has been granted for this version to appear here (http://dx.doi.org/10.1016/S1569-3732(04)09004-8). Emerald does not grant permission for this article to be further copied/distributed or hosted elsewhere without the express permission from Emerald Group Publishing Limited. 
These findings are consistent with the arguments made by Maug (1998)- that when the stock market is relatively liquid, large shareholders have less incentive to monitor managers. It is more profitable for such investors to acquire a block large enough to pressure managers to make quick changes to increase share value and then sell their block, which, in turn, frees up capital to repeat the strategy. A liquid stock market, such as that in the United States, allows for investors to pursue such a strategy.

This study makes three contributions. First, the findings of this study contribute to our understanding of the lack of blockholder activism. Prior researchers have investigated the rationale of the activism by public pension funds ( Romano, 1993; Murphy and Van Nuys, 1994; Wahal, 1996; Karpoff, Malatesta and Walking, 1996; Smith, 1996; Gillan and Starks, 1998; and Del Guercio and Hawkins, 1998). Del Guercio and Hawkins (1998) suggest that the strategies of institutional investors drive the form their activism takes. They show that because many public pension funds are indexed, publicly targeting a particular firm included in the index to improve its performance induces other firms included in that index to make changes to avoid also becoming a target.

Money managers and mutual fund mangers that actively manage their portfolios do not have these same incentives. Since they can buy and sell stocks freely without the constraints of indexing, the performance of their portfolios may be enhanced by making quick changes that immediately improve the stock price on their announcement such as the replacement of the CEO and the restructuring of assets. In contrast, changes that take longer to implement, such as increasing board independence and effectiveness, will show up in higher stock value only after a significant time lag. The criticism that professional 
investors are not active in determining corporate governance practices ignores the nature of their in-and -out investment strategies. These give such investors little incentive or ability to take actions that pay-off in the long run.

Second, this paper suggests that the length of time a buyer maintains block ownership in a firm is critical to observing changes in firm policies following a block acquisition. No study to date (see Holderness, 2003) has examined how the duration of block ownership impacts changes in firm policy and firm value. The results in this paper show that such changes are positively correlated with the length of time the investor holds a block. Third, this paper adds to previous research on the role that blockholders play in changing CEO compensation. While prior researchers have looked at how the structure of CEO compensation varies with the structure of equity ownership (Mehran, 1995), researchers have not examined whether changes in ownership structure cause changes in CEO compensation. This study does and finds that when a new outside investor owns a block for more than a year, the board is pressured to increase equity based compensation and decrease total cash payments to the CEO.

The next section of this paper describes the sample and data and follows with a section that reports descriptive characteristics of the block acquisitions. Subsequent sections report the results on changes in the firm around block acquisitions and investigates the new blockholders' holding period. The last section concludes with a discussion of the study's limitations and suggestions for future research.

This article is ( Emerald Group Publishing and permission has been granted for this version to appear here (http://dx.doi.org/10.1016/S1569-3732(04)09004-8). Emerald does not grant permission for this article to be further copied/distributed or hosted elsewhere without the express permission from Emerald Group Publishing Limited. 


\section{SAMPLE AND DATA}

Data on blockholders, defined as the ownership of $5 \%$ or more of a public corporation's shares, must meet the Securities and Exchange Commission requirements for disclosure. An individual investor or corporation acquiring a block of stock must file a 13D within 10 days of reaching the $5 \%$ threshold. The filing must state whether or not the acquisition is for the purpose of changing or influencing the control of the firm.

Subsequent one percent changes in ownership interests require an amended 13D. In contrast, institutional investors who become blockholders in the ordinary course of their business and with no intention of changing or influencing control of the firm need only file the simpler $13 \mathrm{G}$ form. This study investigates only 13D block acquisitions because such blockholders are more likely to attempt to change the firm's corporate governance than those filing a $13 \mathrm{G}$ form.

Barron's, weekly publication, lists all new 13D filings as well as their amendments from the previous week. A sample of 665 13D filings is obtained from the Barron's issues July 3, 1989 to May 28, 1990. To be included in the sample, the firm whose stock is being acquired must have a CUSIP so that accounting data that can be collected from Compustat. This requirement reduces the final sample to 386 filings for 252 firms. Also excluded from the sample were 58 13D filings in which the purchaser could not be identified (sales of blocks). Finally, proxy statements must be available for one year prior to the block acquisition and two years afterwards to identify changes in the composition in the board and compensation of the CEO. This last requirement reduces the sample to 156 transactions of block acquisitions involving 92 different firms. One hundred and two of these acquisitions were made in 1989 and 54 in 1990.

This article is $\odot$ Emerald Group Publishing and permission has been granted for this version to appear here (http://dx.doi.org/10.1016/S1569-3732(04)09004-8). Emerald does not grant permission for this article to be further copied/distributed or hosted elsewhere without the express permission from Emerald Group Publishing Limited. 
The notation for the years surrounding the block acquisition is $-1,0,+1,+2$, with 0 representing the year for the proxy closest to the block acquisition date. Year $-1,+1$, +2 represent the years before and after the block acquisition. While the data for year 0 is reported, the potential for reporting lags for this year led to its exclusion from statistical tests. Hypothesis tests center around changes in the proxy data from year -1 to years +1 and +2 .

Data on CEO compensation includes the CEO's common stock ownership, common stock options granted and total cash compensation. Since the SEC does not require firms to report salary and cash bonuses separately, not all firms in the sample have this information and thus it is not used in tests of changes in CEO incentive compensation. Data on board compensation includes the number of directors and the percentage of outside directors, defined as those with no obvious ties to management. These are non-management directors that exclude retired managers of the firm; members of management's family; banks, lawyers, accountants, trustees, and other business professionals that have a business relationship with management as disclosed in the proxy statement. Compustat provides operating income before depreciation and amortization, EBITDA (item \#13), total assets (item \#6) and total sales (item \#12). Finally, The Wall Street Journal Company Summary News Index identifies events related to takeovers, restructurings, and shareholder dissidence for the 12 months prior to the block acquisition and the 12 months afterwards.

This article is ( Emerald Group Publishing and permission has been granted for this version to appear here (http://dx.doi.org/10.1016/S1569-3732(04)09004-8). Emerald does not grant permission for this article to be further copied/distributed or hosted elsewhere without the express permission from Emerald Group Publishing Limited. 


\section{TYPE OF INVESTOR, SIZE OF BLOCK, AND METHOD OF ACQUISITION}

I follow Bethel, Liebeskind, and Opler (1998) in my classification scheme of types of outside investors that purchase a $5 \%$ or greater block. Blockholders are classified as either activist, financial, or strategic. Activist blockholders are those identified by Bethel, Liebeskind, and Opler (1998), Denis and Serrano (1996), and Peck (1996) and include "raiders" such as Victor Posner, equity holding companies such as Gabelli Funds, and individuals such as Fayez F. Sarofim. Financial blockholders are defined as banks, pension funds, non-bank trusts, insurance companies and brokerage firms. Strategic blockholders are miscellaneous corporations such as Archer Daniels Midland Company.

Table 1 reports the type of investors making block acquisitions. The majority of investors making acquisitions are activist blockholders, followed by financial and then strategic buyers. These results are similar to those found by Bethel, Liebeskind, and Opler (1998) indicating that the sample has the usual collection of blockholders.

Furthermore, to the extent that most of the blockholders in the sample have been characterized as activists elsewhere suggests that our sample has a significant representation of those blockholders that would be most active in corporate governance issues.

\section{INSERT TABLE 1 ABOUT HERE}

Table 1 also reports how the blocks are acquired because the method of acquisition in the sample could explain the results. For example, if most of the acquisitions are negotiated trades, then the selling blockholder may have already instituted corporate

This article is (c) Emerald Group Publishing and permission has been granted for this version to appear here (http://dx.doi.org/10.1016/S1569-3732(04)09004-8). Emerald does not grant permission for this article to be further copied/distributed or hosted elsewhere without the express permission from Emerald Group Publishing Limited. 
governance changes. The method of acquiring the block is defined by the dates of the acquisition and the identity of the seller (in the case of negotiated trades) reported by Barron's from the information in the 13D. A negotiated acquisition (about $5 \%$ of the sample) is defined as one in which an intact block is transferred from one investor to another. We defined a "block" trade ( $8 \%$ of the sample) as one in which the seller is not identified but the acquisition occurs within one day. In these transactions, it is likely that a larger block is assembled from several smaller ones (see Madhavan and Cheng, 1997). An open market accumulation is defined as one in which there is no identifiable seller and the acquisition takes more than one day. These are the majority $(87.18 \%)$ of the block acquisitions and on average take between 4 and 5 weeks to complete. Thus most of the block acquisitions in the sample represent newly created blocks and reflect a major increase in concentration in outside share ownership. Thus pre-existing outside blockholders are unlikely to have eliminated opportunities to change the firm's corporate governance practices.

Finally, Table 1 reports the size of the block acquired. The typical size is between 10 and $14 \%$ depending on the type of investor. Again, the size is comparable to other studies reporting block size (see Denis and Serrano, 1996; and Peck, 1996). Thus it is unlikely that the sample includes smaller than usual block purchases leading to lesser incentives for acquirers to change corporate governance practices.

In summary, the type of investors, size of block, and method of acquisition are comparable to those reported by other studies of block acquisitions. Thus there is nothing unusual in the type of block acquisitions in the sample that may provide an explanation for the lack of changes in corporate governance after a block acquisition. 


\section{CHANGES IN THE FIRM AFTER A BLOCK ACQUISITION}

The next sections report: (1) the events that occurred after the new blockholder became a shareholder such as takeovers, restructuring activity, and shareholder dissidence; (2) the replacement of the CEO and changes in the structure of the CEO's compensation; and (3) the changes in the board of directors.

\section{Significant Events}

Table 2 reports the events that occur in the year before and after a block acquisition for all block acquisitions in the sample by different types of investors. It shows that there is considerable takeover activity around block acquisitions. Takeover activity includes takeovers that are attempted as well as rumors of impending ones. Other researchers also have found that block acquisitions occur during takeover activity for a variety of reasons: to acquire a "toehold" prior to a takeover attempt (see Mikkelson and Ruback, 1985; and Holderness and Sheehan, 1986); to facilitate improvements in firms with failed takeovers (see Bethel, Liebeskind, and Opler, 1998; and Denis and Serrano, 1996); or to facilitate transfers of control (see Peck, 1996). Table 2 also shows that there is no significant difference in the level of such activity after the acquisition among the various types of investors. This is to be expected since the sample excludes firms that were successfully acquired and no longer report as independent firms board composition or CEO compensation.

TABLE 2 ABOUT HERE

This article is $\odot$ Emerald Group Publishing and permission has been granted for this version to appear here (http://dx.doi.org/10.1016/S1569-3732(04)09004-8). Emerald does not grant permission for this article to be further copied/distributed or hosted elsewhere without the express permission from Emerald Group Publishing Limited. 
Table 2 also reports changes in the frequency of restructuring activity defined as spin offs, acquisitions, joint ventures or acquisitions of a large blocks of stock in another company, layoffs, or the closing of units/ plants, and the sales of business units. Table 2 shows that the frequency of restructuring activity increases significantly after a block acquisition and occurs largely after the acquisition of a block by an active investor. Such investors, which include "raiders" with the reputation of sometimes taking over a company, are more likely to pressure management to restructure the operations of the corporations. These findings are consistent with those of Bethel, Liebeskind, and Opler (1998) who also report an increase in restructuring events after the purchase of a block by an active investor. Table 2 shows that a significant increase in restructuring activity occurs with strategic investors. This is to be expected as strategic investors cause the firm to strategically realign its assets.

Table 2 also reports any dissident activity by shareholders such as bringing a lawsuit against management or waging a proxy fight. Table 2 shows that these events occur less often than either takeover rumors or attempts at restructurings. This finding is consistent with reports in the financial press that other than public pension funds, most professional investors are not activists in matters of corporate governance.

\section{Replacement of the CEO and Changes in CEO Compensation}

Table 3 reports the frequency with which the CEO is replaced and changes in the CEO compensation package after the block acquisition. Table 3 shows that the frequency with which CEOs are replaced is significantly higher in the year following the block

This article is $\odot$ Emerald Group Publishing and permission has been granted for this version to appear here (http://dx.doi.org/10.1016/S1569-3732(04)09004-8). Emerald does not grant permission for this article to be further copied/distributed or hosted elsewhere without the express permission from Emerald Group Publishing Limited. 
acquisition. These results hold for acquisitions by active and financial investors but not for strategic investors. Again these results are similar to those of Bethel, Liebeskind, and Opler, 1998; Denis and Serrano, 1996; and Barclay and Holderness, 1991.

\section{TABLE 3 ABOUT HERE}

The replacement of the CEO is also likely to provide an opportunity to restructure the CEO's compensation contract. Thus blockholders may not only be involved in removing a poorly performing CEO but also improving a poorly structured compensation contract. Table 3 shows the number of options granted to the CEO as a percentage of the stock outstanding increase in the year following the block acquisition. The increase in stock option grants occurs largely with acquisitions by financial investors as does the significant increase in the percentage of stock held by the CEO.

Two conclusions can be drawn from this finding. First, because approximately only a third of the block acquisitions (48 financial buyers out of 156 total) are associated with a significant increase in stock based compensation it is unlikely that the observed increase for the financial buyers reflects a general trend towards more equity based compensation. Second, and more importantly, it suggests that blockholder activism takes different forms depending on the type of blockholder. In the previous section, it is shown that restructuring activities are more likely to take place when the blockholder is either an active or strategic investor; financial buyers do not appear to increase the amount of firm restructuring. However, they apparently do put pressure to have CEO compensation contracts to include more option grants.

This article is $@$ Emerald Group Publishing and permission has been granted for this version to appear here (http://dx.doi.org/10.1016/S1569-3732(04)09004-8). Emerald does not grant permission for this article to be further copied/distributed or hosted elsewhere without the express permission from Emerald Group Publishing Limited. 
Various correlated omitted variables are explored to determine whether the firms in which financial buyers that purchase blocks of stock are different than those of other investors and whether these differences may be the underlying causes of the observed changes towards the CEO compensation that is more stock based. Differences in firm size (total assets and total sales), firm performance (EBITDA/ total assets and EBITDA/ total sales), and CEO compensation between block acquisitions by financial investors and all other investors are reported in Table 4.

\section{TABLE 4 ABOUT HERE}

The table shows that the average size of total assets in year -1 for firms where financial investors acquire a stake is $\$ 694$ million versus $\$ 1794$ million for all other blockholders, a difference statistically significant at the 5\% level. Clearly financial investors focus on smaller firms. Bethel, Liebeskind, and Opler (1998) find that active blockholders purchase stakes in larger, more diversified firms where there are greater opportunities to increase share value by restructuring the firm's assets. They find no evidence of such activity by financial buyers but they do observe an increase in ROA following an acquisition by a financial buyer. They conclude that financial buyers perhaps engage in "quiet diplomacy" to improve a firm's performance. This study provides evidence that shows that financial buyers" "quiet diplomacy" takes the form of

pressuring the board to change the CEO's compensation package to include more equity based incentives.

This article is ( Emerald Group Publishing and permission has been granted for this version to appear here (http://dx.doi.org/10.1016/S1569-3732(04)09004-8). Emerald does not grant permission for this article to be further copied/distributed or hosted elsewhere without the express permission from Emerald Group Publishing Limited. 
Alternatively, size may reflect that financial buyers acquire stock in smaller growth oriented firms. Table 4 also shows that EBITDA/ total sales is on average higher in years 0 and +1 at the 5\% and $10 \%$ level respectively for firms with financial buyers than all other firms. The spurt in the return on sales suggests these firms may have been smaller ones poised for higher growth. Table 4 also shows that total cash compensation as a percentage of total assets is also statistically significant less for firms with financial buyers than all other firms. Growth firms tend also to compensate CEOs with less cash and more equity based incentives than mature ones (see Smith and Watts,1992). Thus the possibility that financial buyers invest in small growth firms that coincidentally increase the CEO's stock and stock option awards cannot be ruled out. Furthermore, as discussed later, most financial buyers have divested within a year, making the likelihood that the increase in the CEO's stock based compensation is the result of pressure from these blockholders less plausible.

\section{Changes in the Board}

Another important way that blockholders can improve the corporate governance of the firm is by making the board more independent. Prior researchers have shown that a higher percentage of outside directors on the board leads to better monitoring of management (see Weisbach, 1988; Byrd and Hickman, 1992; Rosenstein and Wyatt, 1990; Shivdasani, 1993; Brickley, Coles, and Terry, 1994; and Cotter, Shivdasani, and Zenner, 1997). One way that blockholders can improve the independence monitoring function of the board is to pressure the existing board to add more outsiders. Table 5 reports the change in the percentage of outsiders that are on the board around block acquisitions. The results show

This article is ( Emerald Group Publishing and permission has been granted for this version to appear here (http://dx.doi.org/10.1016/S1569-3732(04)09004-8). Emerald does not grant permission for this article to be further copied/distributed or hosted elsewhere without the express permission from Emerald Group Publishing Limited. 
that there are no statistically significant changes either for the entire sample of block acquisitions or any of the sub-samples of investor types. Yermack (1996) has shown that smaller boards are more effective. Another way then that blockholders can improve the board is to reduce the number of directors. Table 5 also shows changes in the number of directors around block acquisitions. There are no statistically significant changes for the entire sample of block acquisitions. Only the median number of directors is significantly smaller at the $10 \%$ level after the acquisition by a financial investor. The findings reported in Table 5 suggest that for the most part outside blockholders do not seek to change the board of directors, a result consistent with earlier discussion of the obstacles to making longer run changes in corporate governance practices.

\section{TABLE 5 ABOUT HERE}

An alternative explanation is that blockholders tend to purchase blocks in companies that already have well functioning boards and no changes are warranted. Yermack (1996) finds that firm value is highest for most firms when board size is between

4 and 8 directors. Table 5 shows that the typical number of directors in the sample is at the upper end of this range. Table 5 also shows that the average board has a majority of outside directors and is likely to be already functioning independent of the CEO.

This article is $\odot$ Emerald Group Publishing and permission has been granted for this version to appear here (http://dx.doi.org/10.1016/S1569-3732(04)09004-8). Emerald does not grant permission for this article to be further copied/distributed or hosted elsewhere without the express permission from Emerald Group Publishing Limited. 


\section{HOW LONG DO BLOCKHOLDERS STAY AND WHAT ARE THE CONSEQUENCES OF LONGER-TERM INVESTMENTS?}

As discussed earlier, one reason that shareholder activism may not take the form of changes in CEO compensation or in the membership of the board is because most professional investors do not own their block long enough to exert pressure on the firm to make these changes or to benefit from them. To investigate this hypothesis, Table 6 reports the number of investors that continue to own a block one and two years after the initial acquisition. Whether the investor continues to own a block or not is determined by whether the shareholder continues to be listed on the firm's proxy statement as a 5\% or more blockholder for years +1 and +2 .

\section{TABLE 6 ABOUT HERE}

Table 6 shows that by the end of year +1 only half of all investors continue to own a $5 \%$ block. By the second year, this had declined to less than a third. Financial investors are the quickest to sell their blocks- only $25 \%$ continue to maintain their investment a year later and only $18 \%$ continue their ownership in the firm in the following year. These findings suggest that financial buyers are more likely to acquire stakes in order to capitalize on quick gains. This conclusion is consistent with the evidence in Table 4 that shows that financial buyers tend to invest in firms that are smaller with a spurt in growth.

Active and strategic buyers maintain their ownership longer. By the end of the second year, $41 \%$ of strategic and $28 \%$ of active investors still have an ownership stake in the

This article is (C) Emerald Group Publishing and permission has been granted for this version to appear here (http://dx.doi.org/10.1016/S1569-3732(04)09004-8). Emerald does not grant permission for this article to be further copied/distributed or hosted elsewhere without the express permission from Emerald Group Publishing Limited. 
firm. Strategic and active buyers' interests are more likely to be long term compared to financial investors that are more likely to be looking for faster returns to their capital.

Table 6 shows that most investors do not continue to hold their block for long enough to effect changes in the firm's corporate governance practices. What about the smaller number of investors that hold their blocks for longer than a year? Table 7 shows the changes in the structure of CEO compensation and board characteristics for investors that continue to own their block in the firm for at least a year. These results suggest that CEO compensation becomes more equity and less cash based and the board becomes more independent when blockholders continue to maintain their investment in the firm.

\section{TABLE 7 ABOUT HERE}

Table 7 shows that in firms where active buyers continue to own a block the CEO is more likely to change and the percentage of options granted increases. However, offsetting the incentive effects from an increase in options grants is a decline in stock ownership. Yet, it is likely that as the CEO is granted more options, he or she decreases their stock ownership to diversify their holdings. Furthermore, stock holdings are also indicative of past options and stock awards as well as the current structure of the CEO's compensation. Table 7 also shows that the percentage of outside directors on the board increases and that the CEO's total cash compensation decreases when strategic buyers maintain their block ownership in the firm. A decline in cash compensation can reflect a decrease in salary and a move to more equity based compensation. Even though the changes in equity based compensation are not statistically significant, Table 7 shows that

This article is ( Emerald Group Publishing and permission has been granted for this version to appear here (http://dx.doi.org/10.1016/S1569-3732(04)09004-8). Emerald does not grant permission for this article to be further copied/distributed or hosted elsewhere without the express permission from Emerald Group Publishing Limited. 
the average percentage of options granted increases for these firms in the sample. While not reported in the table, no statistically significant changes are found for the 12 firms where financial buyers maintain their ownership in the firm for one year. Nor are there any statistically significant changes found in CEO compensation or board characteristics for firms where active or strategic buyers sold their block within a year.

Of course, changes in firm size and performance can confound the findings reported in Table 7. For example, total cash compensation can decline because the firm's accounting earnings have declined leading to a lower accounting based cash bonus. Table 8 reports the results of a logit regression that seeks to explain a buyer's decision to maintain their block ownership in the firm and includes corporate governance characteristics as well as measures of firm size and performance. The independent variables in the year before the block acquisition are included since these are likely to influence the level of the independent variables in the year after the block acquisition. ${ }^{6}$ In addition, a dummy variable for a change in the CEO in year +1 is included since Farrell and Whidbee (2000) show that CEO changes often lead to changes in the board and changes in the CEO can lead to a restructuring of compensation contracts.

\section{TABLE 8 ABOUT HERE}

\footnotetext{
${ }^{6}$ Alternatively, the percentage change in these variables could be used as explanatory variables. They are not used since these variables tend to exacerbate the statistical problems created by outliers. For example, a small absolute change in the percentage of options granted can lead to a very large percentage change when the initial level of the options granted is close to zero.
}

This article is $\odot$ Emerald Group Publishing and permission has been granted for this version to appear here (http://dx.doi.org/10.1016/S1569-3732(04)09004-8). Emerald does not grant permission for this article to be further copied/distributed or hosted elsewhere without the express permission from Emerald Group Publishing Limited. 
The results in Table 8 show that blockholders are more likely to maintain their investment when cash compensation is lower and the percentage of options granted is higher. These findings suggest that CEO compensation is more likely to become more equity and less cash based when investors continue to hold a block in the firm for more than a year. These changes are likely to increase the CEO's incentives to increase shareholder value. Surprisingly, board size and independence is not significantly related to a buyer's decision to maintain their block holdings for more than a year. However, as mentioned earlier, it is likely that blockholders invest in companies that have well functioning boards that will facilitate their efforts to change the structure of the CEO's compensation.

\section{CONCLUSIONS, LIMITATIONS, AND SUGGESTIONS FOR FUTURE}

\section{RESEARCH}

This study documents that restructuring and CEO replacements increase significantly after a block acquisition; findings already documented by other researchers. This study extends their results by investigating whether block acquisitions also lead to changes in CEO compensation and board characteristics, important dimensions of the firm's governance practices. The overall pattern of results indicates that purchasers of a block do not play a significant role in improving the independence and effectiveness of the board or increasing the amount of incentive compensation for the CEO. The study also documents that the majority of professional investors have sold their block within a year. This short holding period suggests that professional owners do not own their stock for a long enough period to alter governance policies that require a stockholder's vote at

This article is $\odot$ Emerald Group Publishing and permission has been granted for this version to appear here (http://dx.doi.org/10.1016/S1569-3732(04)09004-8). Emerald does not grant permission for this article to be further copied/distributed or hosted elsewhere without the express permission from Emerald Group Publishing Limited. 
the annual meeting. Nor do blockholders hold their shares long enough to benefit from these changes. We do find, however, that for some firms where investors do maintain their block ownership for more than a year, that CEO compensation becomes less cash and more equity based.

There are two major limitations to the study that provide opportunities for additional research. First, a sample of block acquisitions is used and not a more random sample. A random sample could address additional questions raised by the results of this study. What firm characteristics attract a blockholder and cause an investor to maintain their block holdings or cause an investor to sell? What is the interaction between the type of blockholder, duration of investment, and the nature of the change in the firm's corporate governance policies and restructuring activities? What is the magnitude of the change in shareholder value associated with different types of changes in these policies? These questions can be answered only with a large random sample of firms that includes a broad cross-section of firms with and without a block acquisition and that tracks changes in corporate governance polices, restructuring activities, and other firm characteristics over a long period of time. The results in this study suggest that such an undertaking is worth while and may lead to additional insights into the ways that different types of blockholders influence the firm's corporate governance polices.

A second limitation of the study is that the sample is more than 10 years old. A disadvantage to using an older sample is that the results may not reflect current business conditions and in particular recent pressures for corporate reform. However, there are two advantages to using an older sample. First, the time period of the sample is consistent with that used in many of the important prior studies of blockholders so that

This article is $\odot$ Emerald Group Publishing and permission has been granted for this version to appear here (http://dx.doi.org/10.1016/S1569-3732(04)09004-8). Emerald does not grant permission for this article to be further copied/distributed or hosted elsewhere without the express permission from Emerald Group Publishing Limited. 
the results are comparable (see Holderness, 2003). This comparison is particularly important to ensure that the results of the study are not driven by something unusual about the sample. Second, because corporate reforms have been only enacted recently, it will be some time before there is sufficient data available to test the impact of these reforms. In the mean time, our study examines the extent to which blockholders influence changes in the firm's corporate governance policies without such reforms. This provides a useful benchmark against which the effect of new reforms on blockholders' behavior can be compared when more data becomes available.

However, current proposals are unlikely to lead to different findings. In 2003, the SEC proposed a new rule to make it easier for long-term large shareholders to nominate directors to the board. ${ }^{7}$ The hope is that greater shareholder involvement in the creation of the board will lead to improvement in it's oversight function. Yet, the findings of this study suggest that the SEC's proposal will yield, at best, only marginal improvements in corporate governance practices. This study has shown that the majority of large shareholders are not long term investors and consequently the SEC's proposal will not apply to them. Corporate reform, then, is unlikely to come from professional money managers since their investment strategy does not give them sufficient incentives to press for longer run changes in the firm's corporate governance practices. Reformers of corporate practices need to seek their support for the changes they hope to have adopted from other institutions and groups. The exceptions may be the very large public pension funds such as that of California or New York City that are large enough to capture the spillover from improvements and have commitments to public policy objectives.

\footnotetext{
${ }^{7}$ See "SEC proposal would give voice to shareholders in board nominations," Milwaukee Journal Sentinel, Milwaukee, Wisconsin, October 9, 2003.
} 
Incentives, such as tax savings, are needed to encourage money managers to make longterm block ownership part of their investment strategy. Otherwise, the rank and file of professional investors is likely to remain in the bleachers in the battle over corporate governance. copied/distributed or hosted elsewhere without the express permission from Emerald Group Publishing Limited. 


\section{References}

Barclay, M.J. and Holderness, C.G. (1991). Negotiated block trades and corporate control. The Journal of Finance 46, 861-879.

Bethel, J.E. , Liebskind, J.P., and Opler, T. (1998). Block Share Purchases and Corporate Performance. Journal of Finance 53, 605-634.

Brickley, J. A., Coles, J.L and Terry, R.L. (1994). Outside directors and the adoption of poison pills. Journal of Financial Economics 35, 371-390.

Byrd, J. W. and Hickman, K. A. (1992). Do outside directors monitor managers? Evidence from tender offer bids. Journal of Financial Economics 32, 195-221.

Cotter, J. F., Shivdasani, A. and Zenner, M. (1997). Do independent directors enhance target shareholder wealth during tender offers? Journal of Financial Economics 43, 195 218.

Del Guercio D. and Hawkins, J. (1999). The motivation and impact of pension fund activism. Journal of Financial Economics 52, 293-340.

Denis, D. J. and Serrano, J.M. (1996). Active investors and management turnover following unsuccessful control contests. Journal of Financial Economics 40, 239-266.

Dodd, P. and Warner, J.B. (1983). On corporate governance: A study of proxy contests. Journal of Financial Economics 11, 401-438.

Farrell, K.A. and Whidbee, D.A. ( 2000). The Consequences of Forced CEO Succession for Outside Directors. Journal of Business 73, 597-627.

Gillan, S. and Starks, L. (1998). Corporate governance proposals and shareholder activism: The role of institutional investors. Unpublished working paper. University of Texas, Austin.

Holderness, C.G. (2003) . A Survey of Blockholders and Corporate Control. Economic Policy Review, forthcoming.

Holderness, C.G. and Sheehan, D.P. (1985). Raiders or saviors? The evidence on six controversial investors. Journal of Financial Economics 14, 555-579.

Karpoff, J., Malatesta, P. and Walking, R. (1996). Corporate governance and shareholder initiatives: empirical evidence. Journal of Financial Economics 42, 365-395.

Madhavan, A. and Cheng, M. (1997). In search of liquidity: Block trades in the upstairs and downstairs markets. The Review of Financial Studies 10, 175-203.

This article is ( E) Emerald Group Publishing and permission has been granted for this version to appear here (http://dx.doi.org/10.1016/S1569-3732(04)09004-8). Emerald does not grant permission for this article to be further copied/distributed or hosted elsewhere without the express permission from Emerald Group Publishing Limited. 
Maug, E. (1998). Large shareholders as monitors: Is there a trade-off between liquidity and control? Journal of Finance 5, 65-98.

Mehran, H. (1995). Executive compensation structuare, ownership, and firm performance. Journal of Financial Economics 38, 163-184.

Mikkelson, W. H., and Ruback, R.S. (1985). An empirical analysis of the interfirm equity investment process. Journal of Financial Economics 14, 523-553.

Murphy, K. and Van Nuys, K. (1994). State pension funds and shareholder inactivism. Unpublished working paper. Harvard Business School, Cambridge.

Peck, S. W. (1996). The influence of professional investors on the failure of management buyout attempts. Journal of Financial Economics 40, 267-294.

Romano, R. (1993). Public pension fund activism in corporate governance reconsidered. Columbia Law Review 93, 795-853.

Rosenstein, S. and Wyatt, J.G. (1990). Outside directors, board independence, and shareholder wealth. Journal of Financial Economics 26, 175-192.

Shivdasani, A. (1993). Board composition, ownership structure and hostile takeover. Journal of Accounting and Economics 16, 167-198.

Shleifer, A. and Vishny, R.W. (1986). Large shareholders and corporate control. Journal of Political Economy 94, 461-488.

Smith, M. P. (1996). Shareholder activism by institutional investors: Evidence from CALPERS. Journal of Finance 51, 227-252.

Smith, C.W. and Watts, R. L. (1992). The investment opportunity set and corporate financing, dividend, and compensation policies. Journal of Financial Economics 32, 263-292.

Wahal, S. (1996). Pension fund activism and firm performance. Journal of Financial and Quantitative Analysis 31, 1-23.

Weisbach, M. S. (1988). Outside directors and CEO turnover. Journal of Financial Economics 20, 431-460.

Yermack, D. (1996). Higher market valuation of companies with a smaller board of directors. Journal of Financial Economics 40, 185-211.

This article is ( E) Emerald Group Publishing and permission has been granted for this version to appear here (http://dx.doi.org/10.1016/S1569-3732(04)09004-8). Emerald does not grant permission for this article to be further copied/distributed or hosted elsewhere without the express permission from Emerald Group Publishing Limited. 
Table 1: Type of Investors and Method of Acquisition for a Sample of 156 blocks for 92 firms from 1989-1990.

\section{Type of Investor ${ }^{a}$ :}

\begin{tabular}{|c|c|c|c|c|}
\hline \multirow{2}{*}{$\begin{array}{l}\text { Method of } \\
\text { Acquisition }{ }^{\mathrm{b}} \text { : }\end{array}$} & Active & Financial & Strategic & TOTAL \\
\hline & & & & \\
\hline $\begin{array}{l}\text { Negotiated } \\
\text { Trade }\end{array}$ & 0 & 0 & 7 & $\begin{array}{l}7 \\
(4.49 \%)\end{array}$ \\
\hline Block & 3 & 4 & 6 & $\begin{array}{l}13 \\
(8.33 \%)\end{array}$ \\
\hline $\begin{array}{l}\text { Open Market } \\
\text { Accumulation }\end{array}$ & 64 & 44 & 28 & $\begin{array}{l}136 \\
(87.18 \%)\end{array}$ \\
\hline $\begin{array}{l}\text { Average time to } \\
\text { accumulate block } \\
\text { (median) } \\
\text { (calendar days) }\end{array}$ & $\begin{array}{l}35.97 \\
(34)\end{array}$ & $\begin{array}{l}40.36 \\
(31)\end{array}$ & $\begin{array}{l}36.13 \\
(32.5)\end{array}$ & $\begin{array}{l}38.48 \\
(34)\end{array}$ \\
\hline $\begin{array}{l}\text { Average size of } \\
\text { Block } \\
\text { (median) } \\
\text { (percentage of } \\
\text { shares } \\
\text { outstanding) }\end{array}$ & $\begin{array}{l}12.08 \% \\
(9.99 \%)\end{array}$ & $\begin{array}{l}12.71 \% \\
(10.545 \%)\end{array}$ & $\begin{array}{l}14.06 \% \\
(11.22 \%)\end{array}$ & $\begin{array}{l}12.79 \% \\
(10.33)\end{array}$ \\
\hline TOTAL & $\begin{array}{l}67 \\
(42.95 \%)\end{array}$ & $\begin{array}{l}48 \\
(30.77 \%)\end{array}$ & $\begin{array}{l}41 \\
(26.28 \%)\end{array}$ & $\begin{array}{l}156 \\
(100 \%)\end{array}$ \\
\hline
\end{tabular}

a Activist blockholders are those identified by Bethel, Liebeskind, and Opler (1998), Denis and Serrano (1996), and Peck (1996) and include "raiders" such as Victor Posner, equity holding companies such as Gabelli Funds, and individuals such as Fayez F. Sarofim. My results do not change when I separate these three groups. Financial blockholders are defined as banks, pension funds, and brokerage firms. Strategic blockholders are miscellaneous corporations such as Archer Daniels Midland Company.

${ }^{\mathrm{b}}$ A negotiated is defined as one in which an intact block is transferred from one investor to another. A block trade is defined as one in which a seller is not identified but the acquisition occurs within one day. An open market accumulation is defined as one in

This article is ( E) Emerald Group Publishing and permission has been granted for this version to appear here (http://dx.doi.org/10.1016/S1569-3732(04)09004-8). Emerald does not grant permission for this article to be further copied/distributed or hosted elsewhere without the express permission from Emerald Group Publishing Limited. 
which there is no identifiable seller and the acquisition takes more than one day to complete.

This article is ( Emerald Group Publishing and permission has been granted for this version to appear here (http://dx.doi.org/10.1016/S1569-3732(04)09004-8). Emerald does not grant permission for this article to be further copied/distributed or hosted elsewhere without the express permission from Emerald Group Publishing Limited. 
Table 2: Changes in the Frequency of Firm Events for a Sample of 156 blocks for 92 firms from 1989-1990.
Year -1
Year $+1^{\text {a }}$

\section{All Block Acquisitions:}

Takeover attempt or rumor $\quad 20$

33

Shareholders sue management 8

13

or wage a proxy fight

Restructuring ${ }^{\mathrm{b}}$

42

$79 * * *$

\section{Active Investors:}

$(\mathrm{n}=67)$

Takeover attempt or rumor

$8+18^{*}$

Shareholders sue management $\quad 0 \quad 5$

or wage a proxy fight

$\begin{array}{lll}\text { Restructuring } & 12 & 35^{* * *}\end{array}$

\section{Financial Investors:}

$(\mathrm{n}=48)$

Takeover attempt or rumor $6 \quad 6$

Shareholders sue management $1 \quad 4$

or wage a proxy fight

$\begin{array}{lll}\text { Restructuring } & 23 & 26\end{array}$

\section{Strategic Investors:}

$(\mathrm{n}=41)$

Takeover attempt or rumor $\quad 6 \quad 6$

Shareholders sue management 7

or wage a proxy fight

$\begin{array}{ll}\text { Restructuring } & 7 \\ & 18^{* * *}\end{array}$ 
$* * *=$ statistically significant at the $1 \%$ level.

$* *=$ statistically significant at the $5 \%$ level.

$*=$ statistically significant at the $10 \%$ level.

${ }^{\text {a }}$ Chi-square test is used to test changes in frequency of events in year -1 to year +1 .

${ }^{\mathrm{b}}$ A restructuring includes spin offs, acquisitions, joint ventures, acquisitions of a large blocks of stock in another company, layoffs, or the closing of units/ plants, sales of business units. 
Table 3: Changes in Frequency of CEO Replacement and Average Compensation Characteristics for a Sample of 156 blocks for 92 firms from 1989-1990 (medians reported in parenthesis).

\begin{tabular}{|c|c|c|c|c|c|}
\hline & & Year-1 & Year 0 & Year +1 & Year $+2^{a}$ \\
\hline \multirow[t]{4}{*}{$\begin{array}{l}\text { All Block } \\
\text { Acquisitions: }\end{array}$} & $\begin{array}{l}\text { Total Cash } \\
\text { Compensation } \\
\text { as a } \\
\text { Percentage of } \\
\text { Total Assets }\end{array}$ & $\begin{array}{l}0.36 \% \\
(0.15 \%)\end{array}$ & $\begin{array}{l}0.36 \% \\
(0.17 \%)\end{array}$ & $\begin{array}{l}0.35 \% \\
(0.14 \%)\end{array}$ & $\begin{array}{l}0.42 \% \\
(0.33 \%)\end{array}$ \\
\hline & $\begin{array}{l}\text { Percentage of } \\
\text { Options }\end{array}$ & $\begin{array}{l}0.21 \% \\
(0.06 \%)\end{array}$ & $\begin{array}{l}0.24 \% \\
(0.04 \%)\end{array}$ & $\begin{array}{l}0.35 \% \\
(0.08 \%)\end{array}$ & $\begin{array}{l}0.42 \% * * * \\
(0.11 \%)\end{array}$ \\
\hline & $\begin{array}{l}\text { Percentage of } \\
\text { Stock }\end{array}$ & $\begin{array}{l}6.75 \% \\
(3.11 \%)\end{array}$ & $\begin{array}{l}6.92 \% \\
(2.88 \%)\end{array}$ & $\begin{array}{l}8.10 \% \\
(2.86 \%)\end{array}$ & $\begin{array}{l}7.43 \% \\
(3.25 \%)\end{array}$ \\
\hline & $\begin{array}{l}\text { Percentage of } \\
\text { CEO replaced } \\
\text { from prior } \\
\text { year }\end{array}$ & & $3.21 \%$ & $19.23 \%$ & $13.46 \% * * *$ \\
\hline \multirow[t]{4}{*}{$\begin{array}{l}\text { Active } \\
\text { Investors: } \\
(\mathrm{n}=67)\end{array}$} & $\begin{array}{l}\text { Total Cash } \\
\text { Compensation } \\
\text { as a } \\
\text { Percentage of } \\
\text { Total Assets }\end{array}$ & $\begin{array}{l}0.39 \% \\
(0.14 \%)\end{array}$ & $\begin{array}{l}0.47 \% \\
(0.17 \%)\end{array}$ & $\begin{array}{l}0.50 \% \\
(0.13 \%)\end{array}$ & $\begin{array}{l}0.65 \% \\
(0.14 \%)\end{array}$ \\
\hline & $\begin{array}{l}\text { Percentage of } \\
\text { Options }\end{array}$ & $\begin{array}{l}0.26 \% \\
(0.02 \%)\end{array}$ & $\begin{array}{l}0.16 \% \\
(0 \%)\end{array}$ & $\begin{array}{l}0.23 \% \\
(0.08 \%)\end{array}$ & $\begin{array}{l}0.29 \% \\
(0.11 \%)\end{array}$ \\
\hline & $\begin{array}{l}\text { Percentage of } \\
\text { Stock }\end{array}$ & $\begin{array}{l}7.02 \% \\
(4.25 \%)\end{array}$ & $\begin{array}{l}6.47 \% \\
(3.54 \%)\end{array}$ & $\begin{array}{l}7.80 \% \\
(2.79 \%)\end{array}$ & $\begin{array}{l}6.81 \% \\
(2.96 \%)\end{array}$ \\
\hline & $\begin{array}{l}\text { Percentage of } \\
\text { CEO replaced } \\
\text { from prior } \\
\text { year }\end{array}$ & & $0 \%$ & $19.40 \%$ & $10.45 \% * * *$ \\
\hline $\begin{array}{l}\text { Financial } \\
\text { Investors: } \\
(n=48)\end{array}$ & $\begin{array}{l}\text { Total Cash } \\
\text { Compensation } \\
\text { as a } \\
\text { Percentage of } \\
\text { Total Assets }\end{array}$ & $\begin{array}{l}0.17 \% \\
(0.15 \%)\end{array}$ & $\begin{array}{l}0.16 \% \\
(0.13 \%)\end{array}$ & $\begin{array}{l}0.19 \% \\
(0.14 \%)\end{array}$ & $\begin{array}{l}0.19 \% \\
(0.11 \%)\end{array}$ \\
\hline
\end{tabular}

This article is ( Emerald Group Publishing and permission has been granted for this version to appear here (http://dx.doi.org/10.1016/S1569-3732(04)09004-8). Emerald does not grant permission for this article to be further copied/distributed or hosted elsewhere without the express permission from Emerald Group Publishing Limited. 


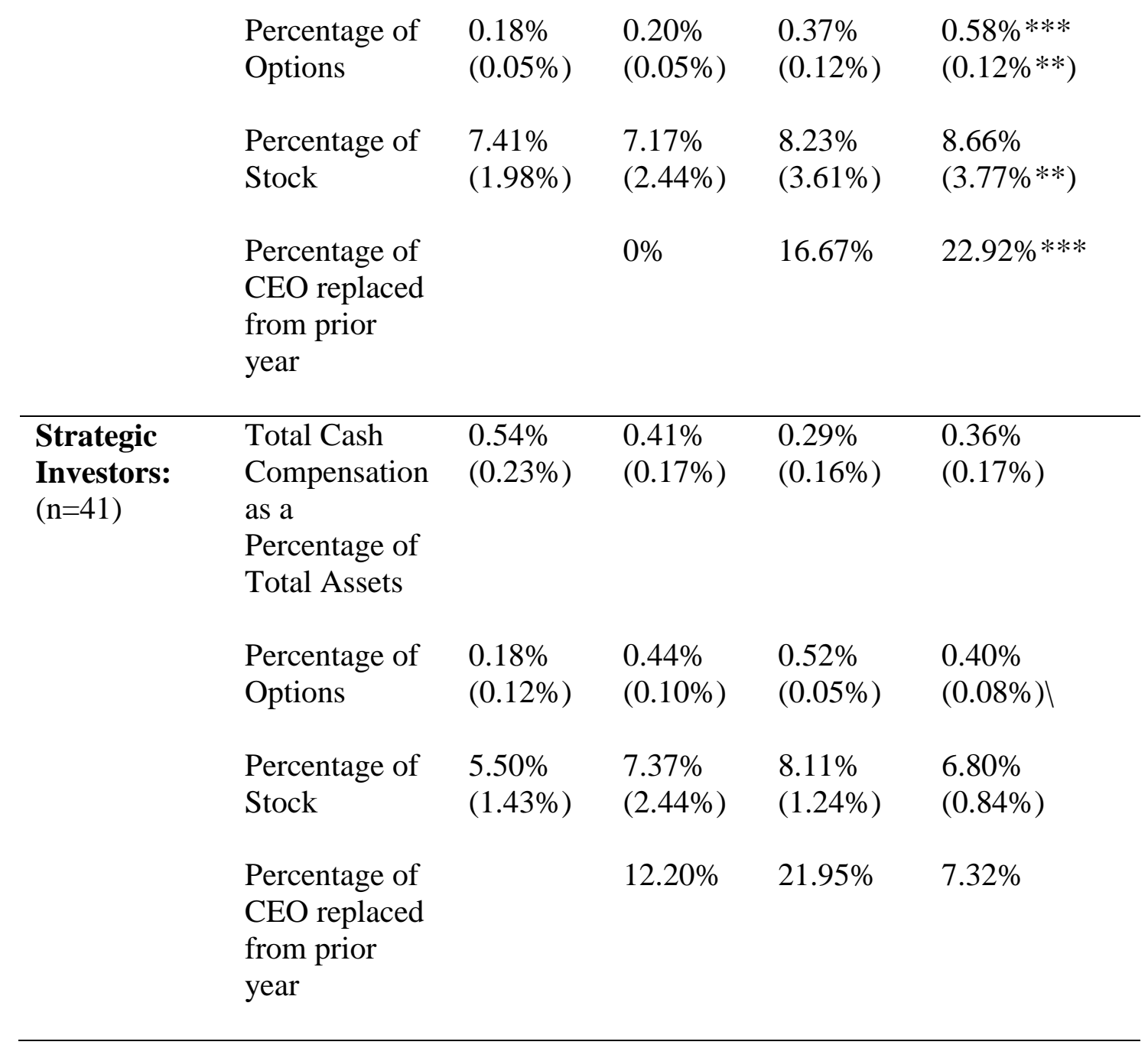

$* * *=$ statistically significant at the $1 \%$ level.

$* *=$ statistically significant at the $5 \%$ level.

$*=$ statistically significant at the $10 \%$ level.

${ }^{a}$ A standard t-test is used to test for a significant difference in means between year -1 and year +2 . A Wilcoxon Sum Rank test is used to test for a significant difference in medians between year -1 and year +2 . The samples are tested for unequal variances and then the appropriate standard t-test or Satterthwaite adjusted t-test is used depending on the outcome of the test for unequal variances. A chi-square test is used to test for a significant difference in the frequency of CEO replacements in years $0,+1$, and +2 .

This article is $\odot$ Emerald Group Publishing and permission has been granted for this version to appear here (http://dx.doi.org/10.1016/S1569-3732(04)09004-8). Emerald does not grant permission for this article to be further copied/distributed or hosted elsewhere without the express permission from Emerald Group Publishing Limited. 
Table 4: Differences in Average Selected Firm Characteristics for Financial Investors versus All other Investors for a Sample of 156 blocks for 92 firms from 1989-1990 (medians reported in parenthesis).

\begin{tabular}{|c|c|c|c|c|c|}
\hline & & Year -1 & Year 0 & Year +1 & Year +2 \\
\hline \multirow[t]{2}{*}{$\begin{array}{l}\text { Total Assets } \\
\text { (millions \$) }\end{array}$} & $\begin{array}{l}\text { Financial } \\
\text { Investors }\end{array}$ & $\begin{array}{l}\$ 694.15 * * \\
(\$ 528.28)\end{array}$ & $\begin{array}{l}\$ 775.37 * * \\
(\$ 485.47)\end{array}$ & $\begin{array}{l}\$ 795.00^{*} \\
(\$ 398.84)\end{array}$ & $\begin{array}{l}\$ 805.54 * * a \\
(\$ 323.55)\end{array}$ \\
\hline & $\begin{array}{l}\text { All Other } \\
\text { Investors }\end{array}$ & $\begin{array}{l}\$ 1,793.61 \\
(\$ 292.76)\end{array}$ & $\begin{array}{l}\$ 1,847.04 \\
(\$ 295.59)\end{array}$ & $\begin{array}{l}\$ 1,943.51 \\
(\$ 292.51)\end{array}$ & $\begin{array}{l}\$ 2,053.45 \\
(\$ 314.78)\end{array}$ \\
\hline \multirow[t]{2}{*}{$\begin{array}{l}\text { Total Sales } \\
\text { (millions \$) }\end{array}$} & $\begin{array}{l}\text { Financial } \\
\text { Investors }\end{array}$ & $\begin{array}{l}\$ 651.31 \\
(\$ 250.83)\end{array}$ & $\begin{array}{l}\$ 702.73 \\
(\$ 267.50)\end{array}$ & $\begin{array}{l}\$ 711.99 \\
(\$ 297.56)\end{array}$ & $\begin{array}{l}\$ 733.87 \\
(\$ 297.54)\end{array}$ \\
\hline & $\begin{array}{l}\text { All Other } \\
\text { Investors }\end{array}$ & $\begin{array}{l}\$ 1,227.28 \\
(\$ 355.83)\end{array}$ & $\begin{array}{l}\$ 1,295.16 \\
(\$ 329.51)\end{array}$ & $\begin{array}{l}\$ 1,395.99 \\
(\$ 383.96)\end{array}$ & $\begin{array}{l}\$ 1,450.88 \\
(\$ 410.90)\end{array}$ \\
\hline \multirow[t]{2}{*}{$\begin{array}{l}\text { EBITDA/ } \\
\text { Total Assets }\end{array}$} & $\begin{array}{l}\text { Financial } \\
\text { Investors }\end{array}$ & $\begin{array}{l}0.05 \\
(0.05)^{* *}\end{array}$ & $\begin{array}{l}0.11 \\
(0.08)\end{array}$ & $\begin{array}{l}0.07 \\
(0.07)\end{array}$ & $\begin{array}{l}0.05 \\
(0.08)\end{array}$ \\
\hline & $\begin{array}{l}\text { All Other } \\
\text { Investors }\end{array}$ & $\begin{array}{l}0.09 \\
(0.09)\end{array}$ & $\begin{array}{l}0.08 \\
(0.05)\end{array}$ & $\begin{array}{l}0.06 \\
(0.06)\end{array}$ & $\begin{array}{l}0.05 \\
(0.07)\end{array}$ \\
\hline \multirow[t]{2}{*}{$\begin{array}{l}\text { EBITDA/ } \\
\text { Total Sales }\end{array}$} & $\begin{array}{l}\text { Financial } \\
\text { Investors }\end{array}$ & $\begin{array}{l}0.05 \\
(0.07)\end{array}$ & $\begin{array}{l}0.36 * * \\
(0.07)\end{array}$ & $\begin{array}{l}0.19 * \\
(0.07)\end{array}$ & $\begin{array}{l}0.07 \\
(0.08)\end{array}$ \\
\hline & $\begin{array}{l}\text { All Other } \\
\text { Investors }\end{array}$ & $\begin{array}{l}0.06 \\
(0.07)\end{array}$ & $\begin{array}{l}0.09 \\
(0.04)\end{array}$ & $\begin{array}{l}0.06 \\
(0.04)\end{array}$ & $\begin{array}{l}0.06 \\
(0.05)\end{array}$ \\
\hline $\begin{array}{l}\text { Total Cash } \\
\text { Compensation }\end{array}$ & $\begin{array}{l}\text { Financial } \\
\text { Investors }\end{array}$ & $\begin{array}{l}0.17 \% * * * \\
(0.15 \%)\end{array}$ & $\begin{array}{l}0.16 \% * * * \\
(0.13 \%)\end{array}$ & $\begin{array}{l}0.19 \% * * \\
(0.14 \%)\end{array}$ & $\begin{array}{l}0.19 \% * * \\
(011 \%)\end{array}$ \\
\hline $\begin{array}{l}\text { as a } \\
\text { Percentage of } \\
\text { Total Assets }\end{array}$ & $\begin{array}{l}\text { All Other } \\
\text { Investors }\end{array}$ & $\begin{array}{l}0.44 \% \\
(0.16 \%)\end{array}$ & $\begin{array}{l}0.45 \% \\
(0.17 \%)\end{array}$ & $\begin{array}{l}0.42 \% \\
(0.15 \%)\end{array}$ & $\begin{array}{l}0.54 \% \\
(0.17 \%)\end{array}$ \\
\hline \multirow[t]{2}{*}{$\begin{array}{l}\text { Percentage of } \\
\text { Options }\end{array}$} & $\begin{array}{l}\text { Financial } \\
\text { Investors }\end{array}$ & $\begin{array}{l}0.18 \% \\
(0.05 \%)\end{array}$ & $\begin{array}{l}0.20 \% \\
(0.05 \%)\end{array}$ & $\begin{array}{l}0.37 \% \\
(0.12 \%)\end{array}$ & $\begin{array}{l}0.58 \% \\
(0.12 \% *)\end{array}$ \\
\hline & $\begin{array}{l}\text { All Other } \\
\text { Investors }\end{array}$ & $\begin{array}{l}0.23 \% \\
(0.07 \%)\end{array}$ & $\begin{array}{l}0.26 \% \\
(0.02 \%)\end{array}$ & $\begin{array}{l}0.34 \% \\
(0.07 \%)\end{array}$ & $\begin{array}{l}0.33 \% \\
(0.10 \%)\end{array}$ \\
\hline \multirow[t]{2}{*}{$\begin{array}{l}\text { Percentage of } \\
\text { Stock }\end{array}$} & $\begin{array}{l}\text { Financial } \\
\text { Investors }\end{array}$ & $\begin{array}{l}7.41 \% \\
(1.98 \%)\end{array}$ & $\begin{array}{l}7.17 \% \\
(2.44 \%)\end{array}$ & $\begin{array}{l}8.23 \% \\
(3.61 \%)\end{array}$ & $\begin{array}{l}8.66 \% \\
(3.77 \% * *)\end{array}$ \\
\hline & All Other & $6.46 \%$ & $6.81 \%$ & $7.91 \%$ & $6.80 \%$ \\
\hline
\end{tabular}

This article is $\odot$ Emerald Group Publishing and permission has been granted for this version to appear here (http://dx.doi.org/10.1016/S1569-3732(04)09004-8). Emerald does not grant permission for this article to be further copied/distributed or hosted elsewhere without the express permission from Emerald Group Publishing Limited. 
$* * *=$ statistically significant at the $1 \%$ level.

$* *=$ statistically significant at the $5 \%$ level.

$*=$ statistically significant at the $10 \%$ level.

${ }^{a}$ A standard t-test is used to test for a significant difference in means between financial and all other investors for each year. A Wilcoxon Sum Rank test is used to test for a significant difference in medians for each year. The samples are tested for unequal variances and then the appropriate standard t-test or Satterthwaite adjusted t-test is used depending on the outcome of the test for unequal variances. 
Table 5: Changes in Average Board Composition and Size for a Sample of 156 blocks for 92 firms from 1989-1990 (medians reported in parenthesis).

\begin{tabular}{|c|c|c|c|c|c|}
\hline & & Year -1 & Year 0 & Year +1 & Year +2 \\
\hline \multirow[t]{2}{*}{$\begin{array}{l}\text { All Block } \\
\text { Acquisitions: }\end{array}$} & $\begin{array}{l}\text { Total } \\
\text { number of } \\
\text { directors }\end{array}$ & $\begin{array}{l}8.63 \\
(8)\end{array}$ & $\begin{array}{l}8.37 \\
(8.5)\end{array}$ & $\begin{array}{l}8.48 \\
(8)\end{array}$ & $\begin{array}{l}8.53^{a} \\
(8)\end{array}$ \\
\hline & $\begin{array}{l}\text { Percentage } \\
\text { of outside } \\
\text { directors }\end{array}$ & $\begin{array}{l}62.09 \% \\
(66.67 \%)\end{array}$ & $\begin{array}{l}63.36 \% \\
(66.67 \%)\end{array}$ & $\begin{array}{l}63.97 \% \\
(66.67 \%)\end{array}$ & $\begin{array}{l}64.70 \% \\
(66.67 \%)\end{array}$ \\
\hline \multirow[t]{2}{*}{$\begin{array}{l}\text { Active } \\
\text { Investors: } \\
(n=67)\end{array}$} & $\begin{array}{l}\text { Total } \\
\text { number of } \\
\text { directors }\end{array}$ & $\begin{array}{l}8.46 \\
(7.5)\end{array}$ & $\begin{array}{l}8.87 \\
(8)\end{array}$ & $\begin{array}{l}8.80 \\
(8)\end{array}$ & $\begin{array}{l}8.97 \\
(9)\end{array}$ \\
\hline & $\begin{array}{l}\text { Percentage } \\
\text { of outside } \\
\text { directors }\end{array}$ & $\begin{array}{l}63.11 \% \\
(66.67 \%)\end{array}$ & $\begin{array}{l}63.13 \% \\
(66.67 \%)\end{array}$ & $\begin{array}{l}63.22 \% \\
(66.67 \%)\end{array}$ & $\begin{array}{l}64.12 \% \\
(66.67 \%)\end{array}$ \\
\hline \multirow[t]{2}{*}{$\begin{array}{l}\text { Financial } \\
\text { Investors: } \\
(n=48)\end{array}$} & $\begin{array}{l}\text { Total } \\
\text { number of } \\
\text { directors }\end{array}$ & $\begin{array}{l}8.73 \\
(9)\end{array}$ & $\begin{array}{l}8.63 \\
(8.5)\end{array}$ & $\begin{array}{l}8.02 \\
(8)\end{array}$ & $\begin{array}{l}7.9 \\
(8) *\end{array}$ \\
\hline & $\begin{array}{l}\text { Percentage } \\
\text { of outside } \\
\text { directors }\end{array}$ & $\begin{array}{l}65.04 \% \\
(63.96 \%)\end{array}$ & $\begin{array}{l}65.35 \% \\
(62.5 \%)\end{array}$ & $\begin{array}{l}65.77 \% \\
(61.54 \%)\end{array}$ & $\begin{array}{l}67.45 \% \\
(67.86 \%)\end{array}$ \\
\hline \multirow[t]{2}{*}{$\begin{array}{l}\text { Strategic } \\
\text { Investors: } \\
(\mathrm{n}=41)\end{array}$} & $\begin{array}{l}\text { Total } \\
\text { number of } \\
\text { directors }\end{array}$ & $\begin{array}{l}8.80 \\
(9)\end{array}$ & $\begin{array}{l}8.68 \\
(9)\end{array}$ & $\begin{array}{l}8.5 \\
(8)\end{array}$ & $\begin{array}{l}8.66 \\
(8.5)\end{array}$ \\
\hline & $\begin{array}{l}\text { Percentage } \\
\text { of outside } \\
\text { directors }\end{array}$ & $\begin{array}{l}56.89 \% \\
(58.33 \%)\end{array}$ & $\begin{array}{l}61.41 \% \\
(66.67 \%)\end{array}$ & $\begin{array}{l}63.05 \% \\
(72.08 \%)\end{array}$ & $\begin{array}{l}62.02 \% \\
(72.08 \%)\end{array}$ \\
\hline
\end{tabular}

$* * *=$ statistically significant at the $1 \%$ level.

$* *=$ statistically significant at the $5 \%$ level.

$*=$ statistically significant at the $10 \%$ level.

${ }^{a}$ A standard t-test is used to test for a significant difference in means between year -1 and year +2 . A Wilcoxon Sum Rank test is used to test for a significant difference in medians between year -1 and year +2 . The samples are tested for unequal variances and

This article is (c) Emerald Group Publishing and permission has been granted for this version to appear here (http://dx.doi.org/10.1016/S1569-3732(04)09004-8). Emerald does not grant permission for this article to be further copied/distributed or hosted elsewhere without the express permission from Emerald Group Publishing Limited. 
then the appropriate standard t-test or Satterthwaite adjusted t-test is used depending on the outcome of the test for unequal variances.

This article is ( E) Emerald Group Publishing and permission has been granted for this version to appear here (http://dx.doi.org/10.1016/S1569-3732(04)09004-8). Emerald does not grant permission for this article to be further copied/distributed or hosted elsewhere without the express permission from Emerald Group Publishing Limited. 
Table 6: Investors that Continue to Hold a 5\% Block after the Initial Acquisition for a Sample of 156 blocks for 92 firms from 1989-1990 (medians reported in parenthesis).

\begin{tabular}{|l|l|l|l|}
\hline & $\begin{array}{l}\text { Listed on Proxy } \\
\text { Statement in year }+1\end{array}$ & $\begin{array}{l}\text { Listed on Proxy } \\
\text { Statement in year }+2\end{array}$ & TOTAL \\
\hline $\begin{array}{l}\text { All Block } \\
\text { Acquisitions }\end{array}$ & $\begin{array}{l}73 \\
(46 \%)\end{array}$ & $\begin{array}{l}45 \\
(28 \%)\end{array}$ & 156 \\
\hline $\begin{array}{l}\text { Active Investors: } \\
\text { (n=67) }\end{array}$ & $\begin{array}{l}37 * * * \text { a } \\
(55 \%)\end{array}$ & $\begin{array}{l}19 * \text { a } \\
(28 \%)\end{array}$ & 67 \\
\hline $\begin{array}{l}\text { Financial } \\
\text { Investors: } \\
\text { (n=48) }\end{array}$ & $\begin{array}{l}12 \\
(25 \%)\end{array}$ & 9 & 48 \\
\hline $\begin{array}{l}\text { Strategic } \\
\text { Investors: } \\
\text { (n=41) }\end{array}$ & $\begin{array}{l}(18 \%) \\
(58 \%)\end{array}$ & $\begin{array}{l}17 \\
(41 \%)\end{array}$ & 41 \\
\hline
\end{tabular}

$* * *=$ statistically significant at the $1 \%$ level.

$* *=$ statistically significant at the $5 \%$ level.

$*=$ statistically significant at the $10 \%$ level.

${ }^{a}$ A chi-square test is used to test for a significant difference in the frequency of type of investors continued to be listed on the proxy statement for year +1 and for year +2 . 
Table 7: Changes in CEO Compensation and Board Characteristics for Investors that Continue to Hold a 5\% Block after the Initial Acquisition for a Sample of 156 blocks for 92 firms from 1989-1990 (medians reported in parenthesis).

\begin{tabular}{|c|c|c|}
\hline & Year -1 & Year +1 \\
\hline \multicolumn{3}{|l|}{ Active Buyers: } \\
\hline $\begin{array}{l}\text { Total CEO Cash } \\
\text { Compensation as a Percentage } \\
\text { of Total Assets }\end{array}$ & $\begin{array}{l}0.00 \\
(0.00)\end{array}$ & $\begin{array}{l}0.00 \\
(0.00)\end{array}$ \\
\hline Percentage of CEO Options & $\begin{array}{l}0.19 \\
(0.00)\end{array}$ & $\begin{array}{l}0.26 \\
(0.14) *\end{array}$ \\
\hline Percentage of CEO Stock & $\begin{array}{l}7.05 \\
(6.15)\end{array}$ & $\begin{array}{l}6.54 \\
(1.64) * *\end{array}$ \\
\hline Total number of Directors & $\begin{array}{l}8.43 \\
(8)\end{array}$ & $\begin{array}{l}8.58 \\
(9)\end{array}$ \\
\hline $\begin{array}{l}\text { Percentage of Outside } \\
\text { Directors }\end{array}$ & $\begin{array}{l}65.11 \\
(71.43)\end{array}$ & $\begin{array}{l}62.58 \\
(69.23)\end{array}$ \\
\hline $\begin{array}{l}\text { Percentage of CEOs replaced } \\
\text { from prior year }\end{array}$ & & $43.24 \% * * *$ \\
\hline \multicolumn{3}{|l|}{ Strategic Buyers: } \\
\hline $\begin{array}{l}\text { Total CEO Cash } \\
\text { Compensation as a Percentage } \\
\text { of Total Assets }\end{array}$ & $\begin{array}{l}0.74 \\
(0.35)\end{array}$ & $\begin{array}{l}0.00 * * \\
(0.00)\end{array}$ \\
\hline Percentage of CEO Options & $\begin{array}{l}0.23 \\
(0.15)\end{array}$ & $\begin{array}{l}0.79 \\
(0.09)\end{array}$ \\
\hline Percentage of CEO Stock & $\begin{array}{l}4.50 \\
(1.43)\end{array}$ & $\begin{array}{l}8.66 \\
(0.69)\end{array}$ \\
\hline Total number of Directors & $\begin{array}{l}7.61 \\
(7)\end{array}$ & $\begin{array}{l}7.91 \\
(8)\end{array}$ \\
\hline $\begin{array}{l}\text { Percentage of Outside } \\
\text { Directors }\end{array}$ & $\begin{array}{l}47.38 \\
(50)\end{array}$ & $\begin{array}{l}60.62 * * \\
(58.33)^{* *}\end{array}$ \\
\hline $\begin{array}{l}\text { Percentage of CEOs replaced } \\
\text { from prior year }\end{array}$ & & $29.17 \%$ \\
\hline
\end{tabular}

This article is $\odot$ Emerald Group Publishing and permission has been granted for this version to appear here (http://dx.doi.org/10.1016/S1569-3732(04)09004-8). Emerald does not grant permission for this article to be further copied/distributed or hosted elsewhere without the express permission from Emerald Group Publishing Limited. 
$* * *=$ statistically significant at the $1 \%$ level.

$* *=$ statistically significant at the $5 \%$ level.

$*=$ statistically significant at the $10 \%$ level.

${ }^{a}$ A standard t-test is used to test for a significant difference in means between year -1 and year +1 . A Wilcoxon Sum Rank test is used to test for a significant difference in medians between year -1 and year +1 . The samples are tested for unequal variances and then the appropriate standard t-test or Satterthwaite adjusted t-test is used depending on the outcome of the test for unequal variances. 
Table 8: Likelihood that Investors that Continue to Hold a 5\% Block after the Initial Acquisition for a Sample of 156 blocks for 92 firms from 1989-1990 (p-values reported in parenthesis).

\begin{tabular}{|c|c|}
\hline Independent Variable & $\begin{array}{l}\text { Parameter estimates from a Logistic } \\
\text { Regression }\end{array}$ \\
\hline Blockholder is a Financial Buyer & $\begin{array}{l}-1.4416 \\
(0.00)^{* * *}\end{array}$ \\
\hline Blockholder is a Strategic Buyer & $\begin{array}{l}1.4414 \\
(0.27)\end{array}$ \\
\hline Blockholder is an Active Buyer & $\begin{array}{l}0.00518 \\
(0.99)\end{array}$ \\
\hline EBITDA/ Total Assets Year -1 & $\begin{array}{l}4.0861 \\
(0.04)^{* * *}\end{array}$ \\
\hline $\begin{array}{l}\text { Total Assets } \\
\text { (millions \$) Year -1 }\end{array}$ & $\begin{array}{l}0.00019 \\
(0.58)\end{array}$ \\
\hline $\begin{array}{l}\text { Total CEO Cash Compensation as a } \\
\text { Percentage of Total Assets Year }-1\end{array}$ & $\begin{array}{l}191.3 \\
(0.13)\end{array}$ \\
\hline Percentage of CEO Options Year -1 & $\begin{array}{l}-0.4584 \\
(0.29)\end{array}$ \\
\hline Percentage of CEO Stock Year -1 & $\begin{array}{l}0.1440 \\
(0.01)^{* * *}\end{array}$ \\
\hline Total number of Directors Year -1 & $\begin{array}{l}-0.1091 \\
(0.17)\end{array}$ \\
\hline Percentage of Outside Directors Year -1 & $\begin{array}{l}-0.0163 \\
(0.43)\end{array}$ \\
\hline $\begin{array}{l}\text { CEO Change from Previous Year in Year } \\
+1\end{array}$ & $\begin{array}{l}0.7175 \\
(0.13)\end{array}$ \\
\hline EBITDA/ Total Assets Year +1 & $\begin{array}{l}-2.4133 \\
(0.25)\end{array}$ \\
\hline $\begin{array}{l}\text { Total Assets } \\
(\text { millions } \$) \text { Year }+1\end{array}$ & $\begin{array}{l}-0.00023 \\
(0.53)\end{array}$ \\
\hline
\end{tabular}


Total CEO Cash Compensation as a

Percentage of Total Assets Year +1

Percentage of CEO Options Year +1

Percentage of CEO Stock Year +1

Total number of Directors Year +1

Percentage of Outside Directors Year +1
$-224.9$

$(0.06)^{* *}$

1.1298

$(0.02)^{* *}$

$-0.1463$

$(0.01)^{* * * *}$

$-0.0341$

(0.72)

0.0120

$(0.52)$

p-value for significance of regression

0.00

$* * *=$ statistically significant at the $1 \%$ level.

$* *=$ statistically significant at the $5 \%$ level.

$*=$ statistically significant at the $10 \%$ level. 